Article

\title{
Effect of Copper Tailing Content on Corrosion Resistance of Steel Reinforcement in a Salt Lake Environment
}

\author{
Liming Zhang ${ }^{1, * \mathbb{D}}$, Jia $\mathrm{Li}^{2}$ and Hongxia Qiao ${ }^{3}$ \\ 1 School of Civil and Architectural Engineering, Nanchang Institute of Technology, Nanchang 330099, China \\ 2 Library, Nanchang Institute of Technology, Nanchang 330099, China; zlm505506533@126.com \\ 3 School of Civil Engineering, Lanzhou University of Technology, Lanzhou 730050, China; \\ 2015994571@nit.edu.cn \\ * Correspondence: zlm_505@nuaa.edu.cn; Tel.: +8615797714900; Fax: 079182121454
}

Received: 22 August 2019; Accepted: 17 September 2019; Published: 20 September 2019

check for updates

\begin{abstract}
With the increasing proportions of copper tailings of concrete in the Qinghai Salt Lake area of China, there arises the problem of corrosion of steel reinforcement in concrete structures. In this study, we determine the corrosion rate $\left(C_{R}\right)$, crack width, and corrosion potential of the steel reinforcement with copper tailing. This was achieved by conducting the constant-current accelerated corrosion test with different proportions of copper tailing in the brine environment of the Qinghai province. The results demonstrate that the corrosion potential $\left(\mathrm{E}_{\mathrm{corr}}\right)$ and the passivation area of the polarization curve decrease with the increase in the corrosion time, and the corrosion rate and crack width increase with the increase in the corrosion time. When the corrosion time is the same, the corrosion potential, crack width, and corrosion depth of the reinforcement decrease first and then increase with the increase in the copper tailing powder content. When the copper tailing powder content is $20 \%$, the above parameters reach the minimum value. In the salt lake environment of Qinghai, China, the copper tailing powder content is recommended to be $20 \%$.
\end{abstract}

Keywords: copper tailing; Qinghai Salt Lake; constant-current acceleration; corrosion resistance

\section{Introduction}

Copper tailings are the residues that remain after the crushing, pickling, and multiple screening of copper ores. These residues have a particle size of less than $0.3 \mathrm{~mm}$. According to relevant data, the Jiangxi province alone has an annual copper tailing heap stock of 496 million tons [1], and the main copper tailings are stored in a reservoir dam (see Figure 1) [2,3], which poses a great threat to the surrounding environment and the safety of residents. Every year, the copper mining enterprises of the Jiangxi province of China spend more than 0.2 billion dollars on the construction, expansion, reinforcement, and health monitoring of tailing dams, and pay an environmental protection tax of more than 1.45 billion dollars. Some non-ferrous metal enterprises have been forced to stop production because they are unable to build new tailing dams. Therefore, it is of utmost importance to recycle the waste copper tailings in the Jiangxi province of China. Recently, research has mainly focused on using copper tailings as fine aggregate [4-6], mineral admixture [7-10], and aerated concrete products [11-13]. Owing to problems, such as low substitution amount and low product quality, the application of the abandoned copper tailings is still in the research stage and has not been widely applied. The results of the chemical composition analysis of the Ruichang copper tailings revealed that the content of pozzolanic active substances, such as $\mathrm{SiO}_{2}, \mathrm{Fe}_{2} \mathrm{O}_{3}$, and $\mathrm{Al}_{2} \mathrm{O}_{3}$, exceeds $70 \%$; therefore, these tailings can be used as mineral admixtures. 
Reinforced concrete is widely used as the basic material in the construction industry. Owing to the effects of high concentrations of chloride salts, the service life of reinforced concrete in the Qinghai Salt Lake area of China is less than 20 years [14-16]. Therefore, improving the corrosion resistance of reinforced concrete in the Qinghai Salt Lake area has become a difficulty in domestic and foreign research [17-19].

Foreign scholars [20,21] add micro-active mineral admixtures into geopolymers to improve the rheological reaction of the geopolymers, so as to prepare materials suitable for 3D printing. Onuaguluchi, $\mathrm{O}$ [22] have focused on the preparation of concrete as a mineral admixture and studied its durability in a chloride salt environment. They found that when the content of copper tailing slag is $10 \%$ of the cementing material, the durability of concrete can be improved, but beyond this content, the durability is deteriorated. Thomas, B.S [23] show that the copper tailing concrete (copper tailings up to $60 \%$ substitution of fine aggregate) exhibited good strength and durability characteristics.

The corrosion resistance of the copper tailing reinforced concrete in the Qinghai Salt Lake area is mainly caused by the corrosion of the steel reinforcement. Most scholars have studied the corrosion of steel reinforcement using the electrified acceleration method, in which the acceleration process usually adopts an immersion method [24-27]. In view of the above problems, this study adopted the constant-current acceleration test to comprehensively analyze the effect of the copper tailings concrete on the corrosion of the steel reinforcement by means of the polarization curve, crack observation, chloride ion content test, and X-ray energy spectrum analysis.

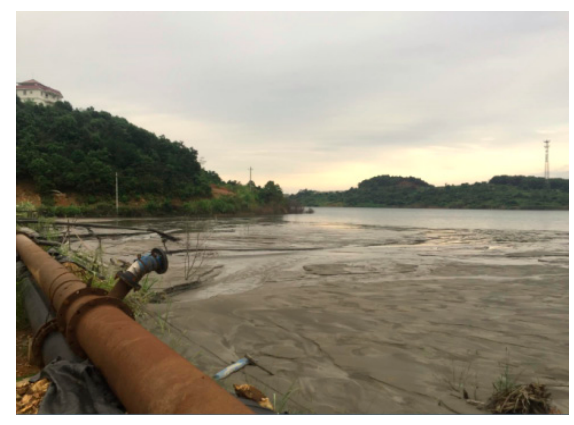

(a)

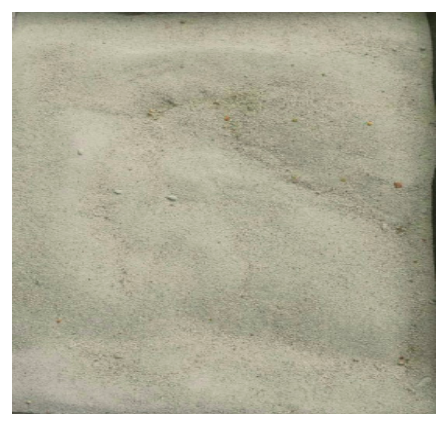

(b)

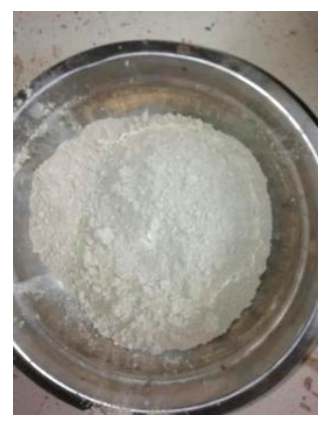

(c)

Figure 1. Copper tailing powder in copper tailing reservoir. (a) Reservoir of copper tailing; (b) copper tailing; (c) copper tailing power.

\section{Test}

\subsection{Raw Materials}

The copper tailings were obtained from Jiangxi province, and their main chemical compositions were $\mathrm{SiO}_{2}, \mathrm{Al}_{2} \mathrm{O}_{3}$, and $\mathrm{CaO}$, with a small amount of $\mathrm{Fe}_{2} \mathrm{O}_{3}$ and $\mathrm{MgO}$, as summarized in Table 1 . To ensure that the fineness of the copper tailing met the requirements of the specification, a special ball mill was used to grind the tailing for $45 \mathrm{~min}$. After grinding, the specific surface area was $410 \mathrm{~m}^{2} / \mathrm{kg}$, and the particle size distribution is illustrated in Figure 2. The cement used was 42.5 ordinary Portland cement, and its chemical composition is listed in Table 1 . The gravel used was $5-16 \mathrm{~mm}$ continuously graded gravel, and the water used was tap water. The concrete test mix ratio and performance of each group are presented in Table 2. The steel plate used was HRB400, which had a diameter of $12 \mathrm{~mm}$.

Table 1. Cementitious material chemical composition.

\begin{tabular}{cccccccc}
\hline Binder Material Type & $\mathrm{SiO}_{\mathbf{2}}$ & $\mathrm{Al}_{\mathbf{2}} \mathrm{O}_{\mathbf{3}}$ & $\mathrm{Fe}_{\mathbf{2}} \mathrm{O}_{\mathbf{3}}$ & $\mathrm{CaO}$ & $\mathbf{M g O}$ & $\mathbf{S O}_{\mathbf{3}}$ & Loss \\
\hline Cement & 66.5 & 5.5 & 3.3 & 15.7 & 1.7 & 2.0 & 5.3 \\
Copper tailing & 58.5 & 6.6 & 15.8 & 12.7 & 2.8 & 3.2 & 0.4 \\
\hline
\end{tabular}


Figure 2 shows SEM (scanning electron microscope) micro-graphs and the XRD (X-ray diffraction) patterns of copper tailing. Figure 2a presents a micro-graph of copper tailing. The majority of grains have an ellipsoidal and flaky shape. The rest of the copper tailing have a spherical shape. The grain surface is smooth. As shown in Figure $2 b$, the main materials of copper tailings are quartz $\left(\mathrm{SiO}_{2}\right)$, and radite $\left(\mathrm{Ca}_{3} \mathrm{Fe}_{2} \mathrm{Si}_{3} \mathrm{O}_{12}\right)$, gypsum $\left(\mathrm{CaSO}_{4}\right)$, which is in accordance with the chemical analysis result that most of the minerals included are rich in $\mathrm{SiO}_{2}$ and $\mathrm{Fe}_{2} \mathrm{O}_{3}$.

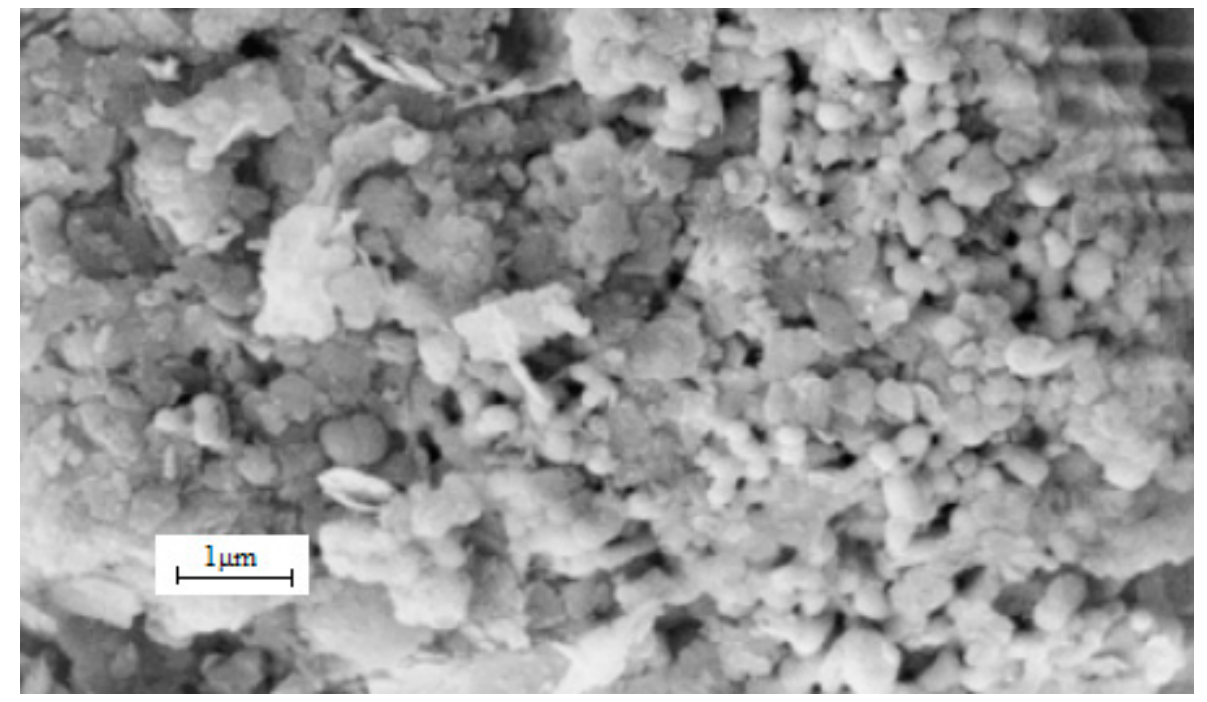

(a)

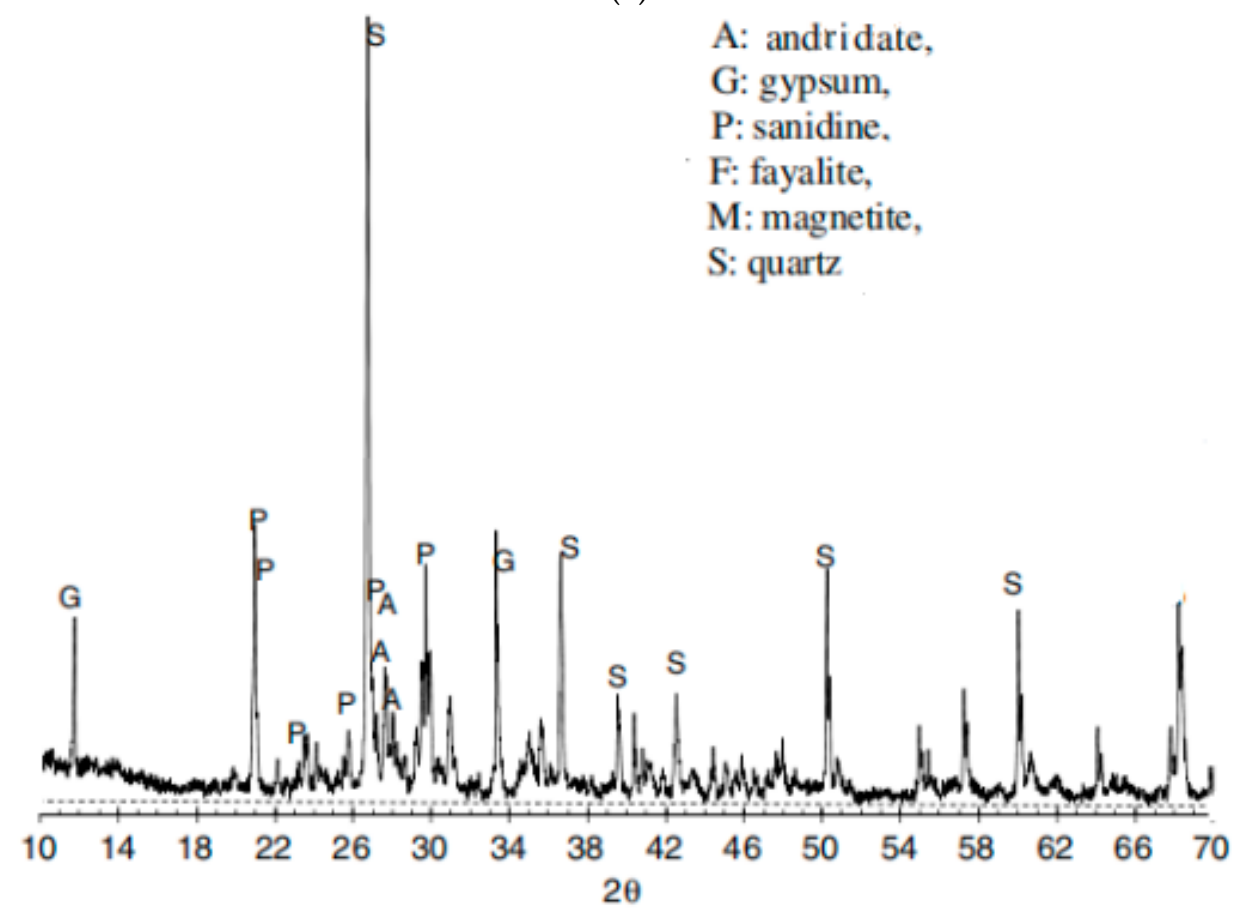

(b)

Figure 2. SEM (scanning electron microscope) and the XRD (X-ray diffraction) of copper tailings: (a) SEM micro-graphs of copper tailings; (b) XRD pattern of copper tailings.

Figure 3 shows the particle size distribution of the raw materials. Figure 3 a shows that the particle size range of the copper tailings is $0-48.1 \mu \mathrm{m}$ and the mean particle size $\left(\mathrm{d}_{\mathrm{m}}\right)$ and Hummel modulus 
$\left(\mathrm{m}_{\mathrm{H}}\right)$ of it is $9.0 \mu \mathrm{m}$ and 22.54 based on the research of Katzer, J. [28]; the particle size range of cement is $0-100 \mu \mathrm{m}$ and the mean particle size $\left(\mathrm{d}_{\mathrm{m}}\right)$ and Hummel modulus $\left(\mathrm{m}_{\mathrm{H}}\right)$ of it is $27.3 \mu \mathrm{m}$ and 22.54 . The mean particle size $\left(\mathrm{d}_{\mathrm{m}}\right)$ of copper tailings is 0.33 times that of cement. The Hummel modulus $\left(\mathrm{m}_{\mathrm{H}}\right)$ of copper tailing is 0.67 times that of cement. The maximum particle size of copper tailing is 0.48 times a of cement. Therefore, copper tailing can be filled in the pores of ordinary Portland cement [29-32].

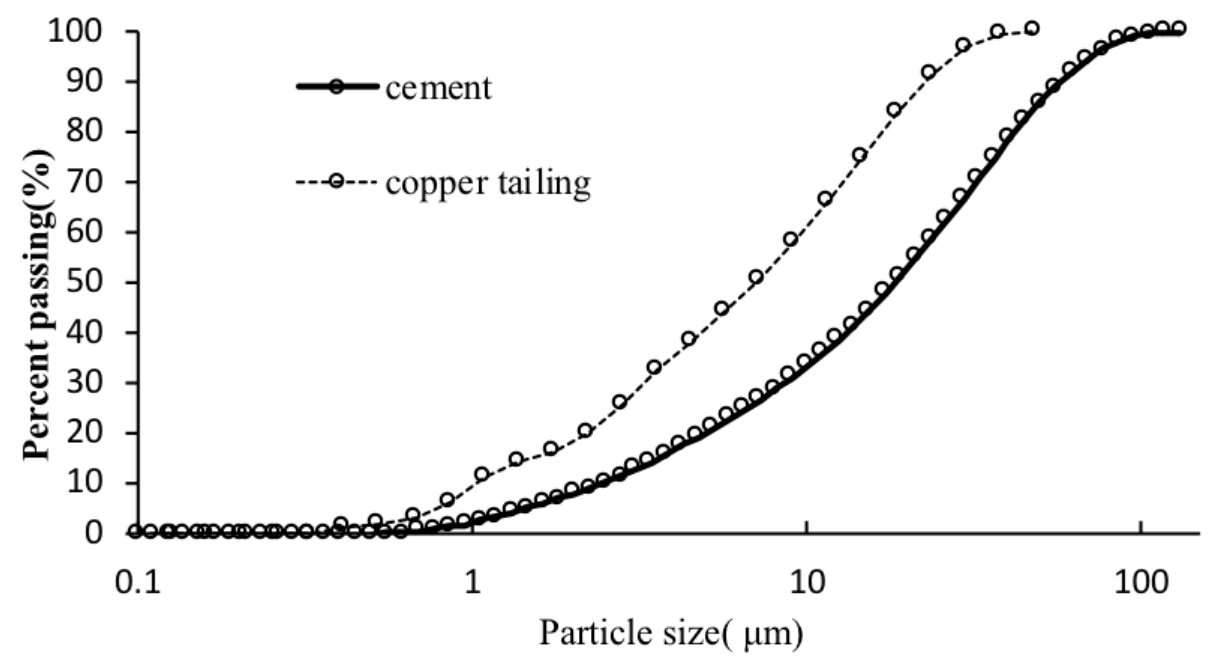

(a)Cumulative particle size distribution

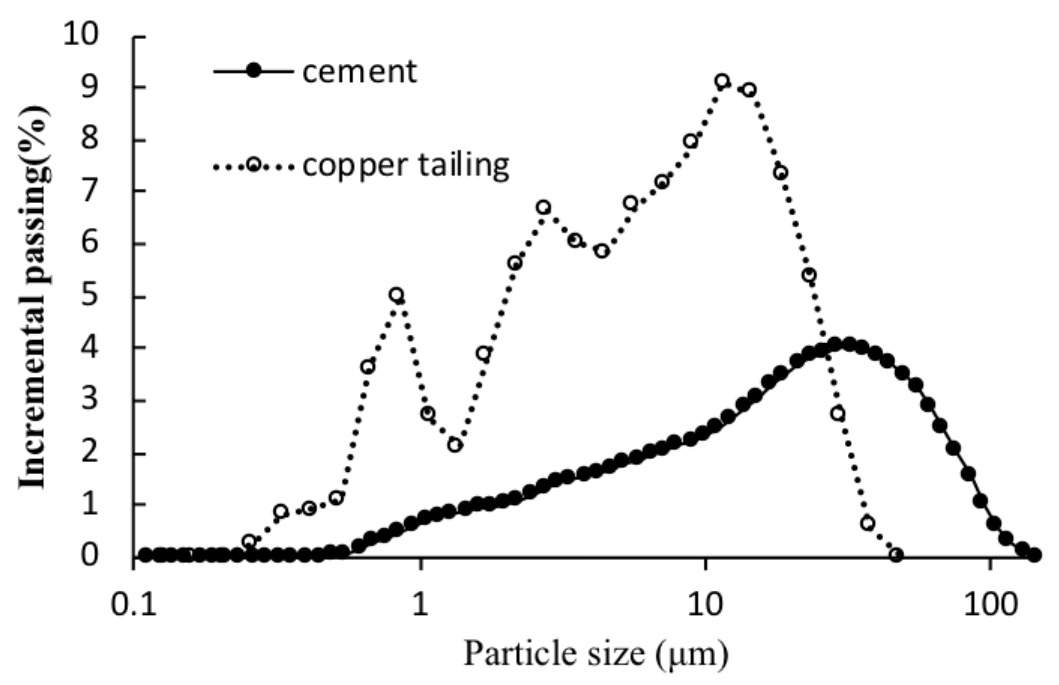

(b)interval size distribution

Figure 3. Particle size distribution of raw materials: (a) Cumulative particle size distribution; (b) interval size distribution.

\subsection{Test Scheme}

Four concrete mixing ratios were designed in this experiment, denoted as P, P10, P20, and P30, respectively, as listed in Table 2.

Each mixing ratio was composed of six $100 \mathrm{~mm} \times 100 \mathrm{~mm} \times 100 \mathrm{~mm}$ reinforced concrete specimens. A steel bar of length $100 \mathrm{~mm}$ was buried in the center of the concrete, with one end exposed $25 \mathrm{~mm}$ from the upper surface of the concrete. The other end was $25 \mathrm{~mm}$ from the bottom of the concrete, and the protective layer thickness of the specimen was set to $25 \mathrm{~mm}$.

The mold was removed after $24 \mathrm{~h}$ once the specimen had formed, and the specimen was placed in an environment having a temperature of $20+2{ }^{\circ} \mathrm{C}$ and relative humidity of $95 \% \mathrm{RH}$ (Relative 
Humidity) for more than $28 \mathrm{~d}$. Then, the sample was configured to simulate the brine of the Qinghai Salt Lake, and a PS-3002D galvanostat was used to conduct the constant-current accelerated corrosion test. When conducting the electrification acceleration test, the current density was set at $200 \mu \mathrm{A} / \mathrm{cm}^{2}$, and the corresponding constant-current was $20 \mathrm{~mA}$.

Chemical composition of Qinghai Salt Lake in China is shown as Table 3.

Table 2. Concrete mixing ratios $\left(\mathrm{kg} / \mathrm{m}^{3}\right)$

\begin{tabular}{cccccccc}
\hline \multirow{2}{*}{ No. } & \multicolumn{5}{c}{ Raw Material Quality $\left(\mathbf{k g} / \mathbf{m}^{\mathbf{3}}\right)$} & Slump/mm & $\begin{array}{c}\text { 28 Day } \\
\text { Compressive } \\
\text { Strength/MPa }\end{array}$ \\
\hline & Cement & Water & Sand & Coarse Aggregate & Copper Tailing & & 98 \\
P & 450 & 158 & 634 & 1167 & 0 & 100 & 50.6 \\
P10 & 405 & 158 & 634 & 1167 & 45 & 105 & 50.6 \\
P20 & 360 & 158 & 634 & 1167 & 90 & 118 & 45.1 \\
P30 & 315 & 158 & 634 & 1167 & 135 & \\
\hline
\end{tabular}

Table 3. Chemical composition of Qinghai Salt Lake, China.

\begin{tabular}{ccccccccc}
\hline Ion Name & $\mathrm{Na}^{+}$ & $\mathbf{M g}^{2+}$ & $\mathbf{K}^{+}$ & $\mathrm{Ca}^{2+}$ & $\mathrm{Cl}^{-}$ & $\mathbf{S O}_{4}{ }^{2-}$ & $\mathbf{C O}_{3}{ }^{2-}$ & $\mathbf{H C O}_{3}{ }^{-}$ \\
\hline $\begin{array}{c}\text { Unit } \\
\left(\mathrm{mg} / \mathrm{dm}^{3}\right)\end{array}$ & 68.36 & 35.13 & 5.98 & 4.24 & 204.21 & 22.29 & 0.17 & 0.13 \\
\hline
\end{tabular}

\subsection{Test Method}

\section{Electrochemical Testing Methods}

An electrochemical workstation was used for the electrochemical testing, in which the reference electrode used was the saturated calomel electrode, and the auxiliary electrode foil tape and steel bar in the reinforced concrete specimen were used as the working electrodes. The polarization curve scanning range was $-200-200 \mathrm{~mA}$, scanning rate was $334 \mathrm{mV} / \mathrm{s}$, and frequency was $0.33 \mathrm{~Hz}$. The polarization curve was measured every $103 \mathrm{~h}$.

According to Faraday's theorem (1) [33], the constant-current acceleration time required for each $1 \%$ increase in the theoretical mass loss rate under the action of a current of $4 \mathrm{~mA}$ can be obtained.

$$
t=\frac{\Delta m \cdot Z \cdot F}{M_{F e} \cdot I} .
$$

Here, $t$ is the electrification time (s); $\Delta m$ is the quality loss of reinforcement (g); $Z$ is the chemical valence of the reaction electrode (+2); $F$ is Faraday's constant $(96,500 \mathrm{c} / \mathrm{mol}) ; M_{F e}$ is the atomic weight of iron $56(\mathrm{~g} / \mathrm{mol}) ; I$ is the current intensity $\left(20 \times 10^{-3} \mathrm{~A}\right)$. The data collection was conducted in cycles of $103 \mathrm{~h}$ durations until cracks of thickness $0.2 \mathrm{~mm}$ or greater appeared on the surface of the concrete specimen, after which the test was stopped.

\section{Results and Discussion}

\subsection{Polarization Curve Results and Analysis}

Figure 4a-d illustrates the polarization curves of the copper tailing reinforced concrete specimens $\mathrm{P}$ (normal concrete), P10 (The quality of copper tailing is 10\% of that of cementing materials), P20 (The quality of copper tailing is $20 \%$ of that of cementing materials), and P30 (The quality of copper tailing is $30 \%$ of that of cementing materials), respectively, after being subjected to the constant-current accelerated corrosion for 0, 103 h, 206 h, 309 h, and 412 h. As illustrated in Figure 4a-c, the corrosion potential exhibited a negative trend with the extension of the accelerated constant-current corrosion, and the polarization curve passivation area gradually narrowed. In Figure 4d, the corrosion potential exhibited a positive trend at $309 \mathrm{~h}$ and $412 \mathrm{~h}$. Therefore, we can conclude that the corrosion potential presents a negative trend when the copper tailing powder content is less than $20 \%$ of the total cement mass. 
At the same corrosion time, the corrosion potential decreases first and then increases with the increase in the copper tailing powder content. Figure $4 a-d$ indicates that the addition of $20 \%$ copper tailing powder had a good inhibition effect on the corrosion of the steel reinforcement at the initial stage of the electrochemical corrosion. As illustrated in Figure 4a, the corrosion potential exhibits a negative trend with the extension of the constant-current accelerated corrosion time. Figure $4 \mathrm{~b}$ illustrates that the corrosion potential of group P10 gradually moved to the negative direction and the corrosion current density moved to the positive direction with the continuous increase of the constant-current accelerating corrosion time, indicating that the reinforcement corrosion becomes more severe with the extension of the constant-current accelerating time. As illustrated in Figure $4 \mathrm{c}$, the corrosion potential of group P20 demonstrated a negative trend with the increase of the corrosion time under constant-current acceleration, but the change in the polarization curve was negligible after $103 \mathrm{~h}$ under constant-current acceleration. As illustrated in Figure $4 \mathrm{~d}$, the corrosion potential exhibits a negative trend with the extension of the constant-current accelerated corrosion time, but exhibits a positive trend at 206, 309, and $412 \mathrm{~h}$. It can be concluded that the accumulation of early corrosion products on the surface of reinforced concrete specimens mixed with $10 \%$ copper tailings may temporarily hinder the development of corrosion. The above results demonstrate that, in the electrochemical corrosion process, when the content of copper tailing powder is less than $20 \%$ of the total cement mass, the inhibition effect on the steel corrosion is better.

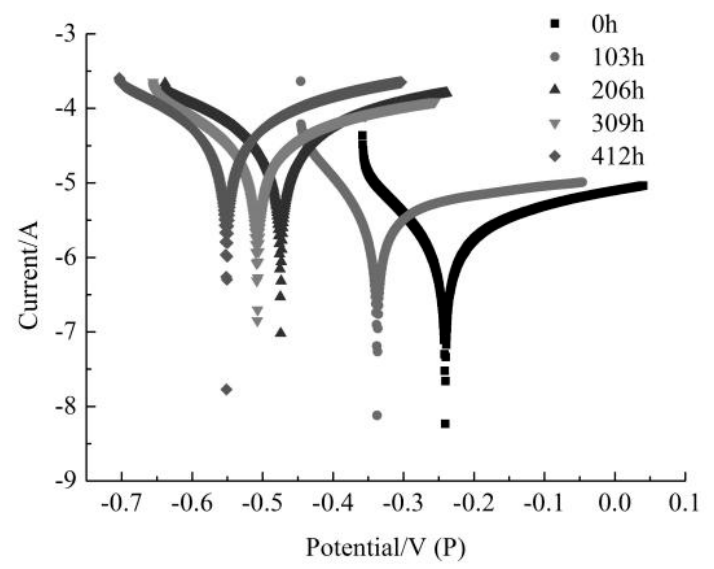

(a) Group P

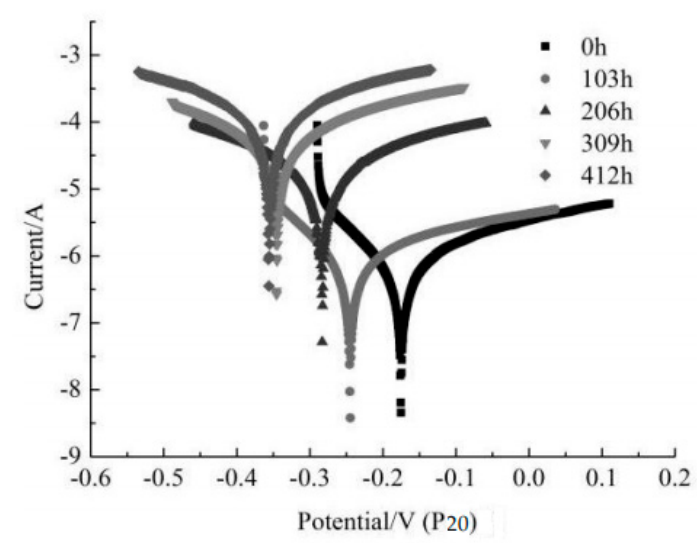

(c) Group P20

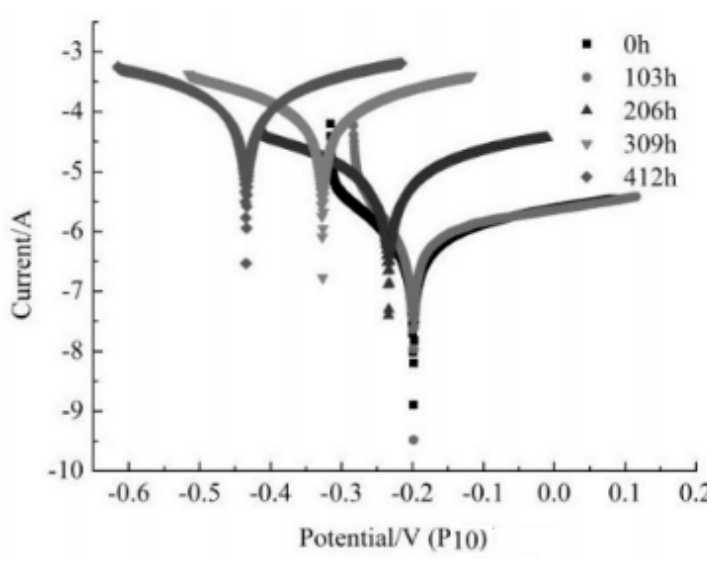

(b) Group P10

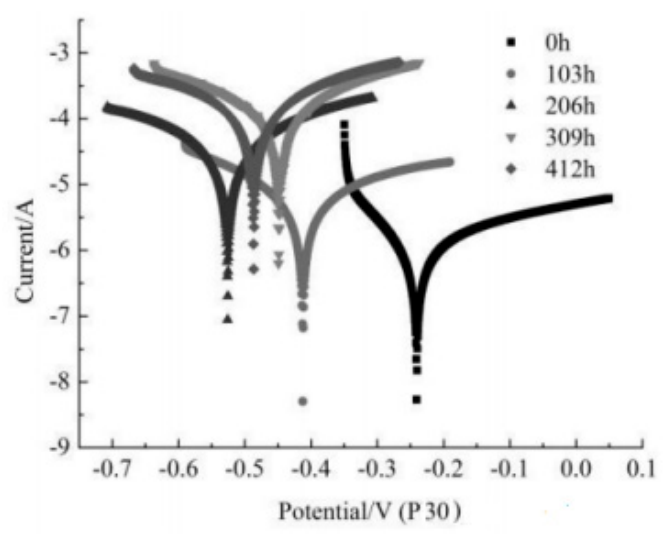

(d) Group P30

Figure 4. Polarization curves of reinforced concrete with different copper tailings. (a) Polarization curves of Group P; (b) polarization curves of Group P10; (c) polarization curves of Group P20; (d) polarization curves of Group P30. 
Figure 5a-c illustrates the SEM photograph of the copper tailing reinforced concrete specimens P10, P20, and P30, respectively, after being subjected to the constant-current for $206 \mathrm{~h}$. The columnar crystal in the concrete hole increases with the increase of the copper tailing content. When the copper tailing content is $20 \%$, the columnar crystal fills the concrete hole and enhances the compacted concrete. When the content of copper tailing is 30\%, the columnar crystals destroy the cement-based material structure around the concrete hole. Figure 5a illustrates that concrete P10 generates chips like bar crystals in holes and grows outward in the direction of holes. Figure 5b illustrates that the crystals generated in concrete P20 are short and thick with irregular distribution, and some honeycomb corrosion products are distributed on the gel surface. As Shown in Figure 5c, Concrete P30 has a large number of needle-rod crystals growing out of the gel, which makes the gel appear layered. The needle-rod crystals gather together and have a high degree of directivity.

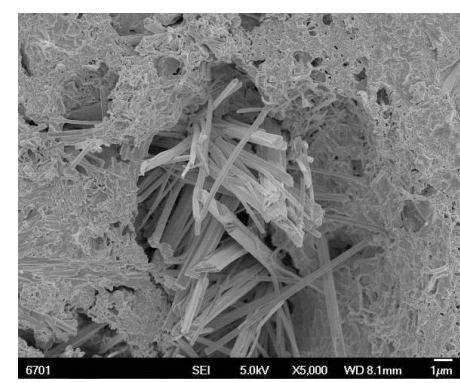

(a)

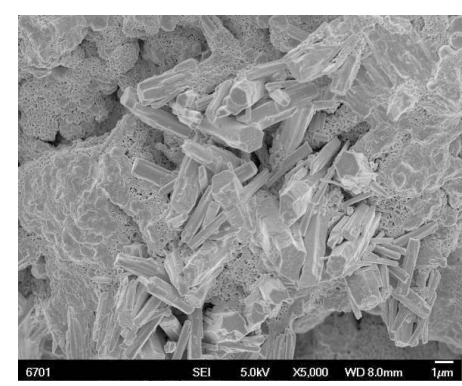

(b)

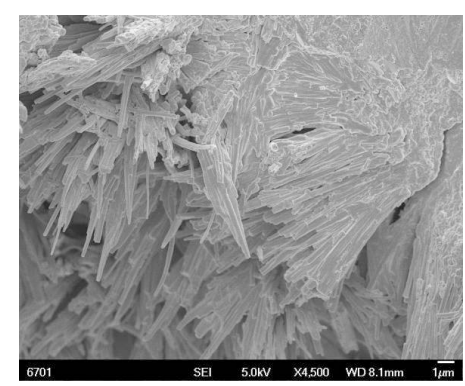

(c)

Figure 5. SEM photograph of reinforced concrete with different copper tailings with $206 \mathrm{~h}$ corrosion time. (a) Group P10; (b) Group P20; (c) Group P30.

The polarization curve is the relation curve between the electrode potential (E) and measured current (I) in the coordinate system in the electrochemical nondestructive testing method and the measured current density [34]. The corrosion of the steel bar is measured by the polarization curve and the corresponding corrosion potential $\left(\mathrm{E}_{\mathrm{corr}}\right)$, corrosion current density $\left(\mathrm{i}_{\text {corr }}\right)$, corrosion rate $\left(\mathrm{C}_{\mathrm{R}}\right)$, and electrochemical etching parameters $\left(\mathrm{E}_{\mathrm{tc}}\right)$. The corresponding relation between the corrosion current density and instantaneous corrosion degree of steel reinforcement is given in literature [35], and is presented in Table 4.

Table 4. Relationship between corrosion current density ( $\left.\mathrm{i}_{\text {corr }}\right)$ and corrosion degree of steel.

\begin{tabular}{cccccc}
\hline$i_{\text {corr }} /\left(\mu \mathrm{A} \cdot \mathbf{c m}^{-2}\right)$ & $i_{\text {corr }}<\mathbf{0 . 2}$ & $\mathbf{0 . 2}<i_{\text {corr }}<\mathbf{0 . 5}$ & $\mathbf{0 . 5}<i_{\text {corr }}<\mathbf{1 . 0}$ & $\mathbf{1 . 0}<i_{\text {corr }}<\mathbf{1 0}$ & $i_{\text {corr }}>\mathbf{1 0}$ \\
\hline Corrosion degree & Passivation state & Low & Moderate & High & Extreme \\
& & corrosion condition & $\begin{array}{c}\text { corrosion condition } \\
\text { corrosion condition }\end{array}$ & corrosion condition \\
\hline
\end{tabular}

Table 5 presents the corrosion electrochemical parameters corresponding to Figure 3a-d. As presented in Table 5, the corrosion current density and corrosion degree of the reinforced concrete specimens with copper tailing powder increase with the increase in electrification time. At $412 \mathrm{~h}$ of constant-current acceleration, the corrosion current density of the reinforced concrete specimens in Group P increased from 0.007 to $1.078 \mu \mathrm{A} \cdot \mathrm{cm}^{-2}$, which is an increase of 154 times.

The corrosion current density of the reinforced concrete specimens in Group P10 increased from the initial 0.008 to $0.724 \mu \mathrm{A} \cdot \mathrm{cm}^{-2}$, which is an increase of 90.5 times. It can be seen from Table 4 that the specimens in this group were moderately corroded at this time. The corrosion current density of the reinforced concrete specimens in Group P20 increased from 0.018 to $0.397 \mu \mathrm{A} \cdot \mathrm{cm}^{-2}$, which is an increase of 22 times. It can be seen from Table 4 that the specimens in this group were slightly corroded at this time. The corrosion current density of the reinforced concrete specimens in group P30 increased from 0.012 to $1.334 \mu \mathrm{A} \cdot \mathrm{cm}^{-2}$, which is an increase of 111 times. It can be seen from Table 4 that the specimens in this group were highly corroded at this time. According to the above 
analysis, after $412 \mathrm{~h}$ of constant-current accelerated corrosion, the order of the degree of corrosion of the steel reinforcement in the specimens from high to low was P30 > P > P10 > P20. This test result is consistent with that presented by Zhang Yunsheng and Sun Wei et al. [36], who suggested that the double-incorporation and single-incorporation of mineral admixtures can significantly improve the corrosion resistance of the steel bars in concrete. Additionally, this test result was consistent with the view proposed by Gao Xiangbiao [37], who suggested that the single-incorporation of mineral powder and fly ash can improve the protection performance of the steel bars in concrete.

Table 5. Electrochemical parameters of the polarization curve.

\begin{tabular}{ccccccc}
\hline No. & $\mathbf{t}(\mathbf{h})$ & $\mathbf{0}$ & $\mathbf{1 0 3}$ & $\mathbf{2 0 6}$ & $\mathbf{3 0 9}$ & $\mathbf{4 1 2}$ \\
\hline \multirow{3}{*}{$\mathrm{P}$} & $\mathrm{E}_{\mathrm{corr}} / \mathrm{V}$ & -0.241 & -0.337 & -0.474 & -0.508 & -0.551 \\
& $\mathrm{i}_{\mathrm{corr}} /\left(\mu \mathrm{A} \cdot \mathrm{cm}^{-2}\right)$ & 0.007 & 0.009 & 0.066 & 0.726 & 1.078 \\
& $\mathrm{C}_{\mathrm{R}} /\left(10^{-3} \mathrm{~mm} \cdot \mathrm{a}^{-1}\right)$ & 0.141 & 0.616 & 3.751 & 11 & 15.47 \\
\hline \multirow{3}{*}{$\mathrm{P10}$} & $\mathrm{E}_{\mathrm{corr}} / \mathrm{V}$ & -0.199 & -0.198 & -0.234 & -0.327 & -0.434 \\
& $\mathrm{i}_{\mathrm{corr}} /\left(\mu \mathrm{A} \cdot \mathrm{cm}^{-2}\right)$ & 0.008 & 0.011 & 0.172 & 0.446 & 0.724 \\
& $\mathrm{C}_{\mathrm{R}} /\left(10^{-3} \mathrm{~mm} \cdot \mathrm{a}^{-1}\right)$ & 0.098 & 0.123 & 1.995 & 5.17 & 8.393 \\
\hline \multirow{3}{*}{ P20 } & $\mathrm{E}_{\mathrm{corr}} / \mathrm{V}$ & -0.175 & -0.245 & -0.283 & -0.346 & -0.356 \\
& $\mathrm{i}_{\mathrm{corr}} /\left(\mu \mathrm{A} \cdot \mathrm{cm}^{-2}\right)$ & 0.018 & 0.040 & 0.299 & 0.256 & 0.397 \\
& $\mathrm{C}_{\mathrm{R}} /\left(10^{-3} \mathrm{~mm} \cdot \mathrm{a}^{-1}\right)$ & 0.209 & 0.466 & 3.466 & 2.972 & 4.6 \\
\hline \multirow{3}{*}{ P30 } & $\mathrm{E}_{\mathrm{corr}} / \mathrm{V}$ & -0.241 & -0.412 & -0.526 & -0.449 & -0.486 \\
& $\mathrm{i}_{\mathrm{corr}} /\left(\mu \mathrm{A} \cdot \mathrm{cm}^{-2}\right)$ & 0.012 & 0.053 & 0.323 & 0.948 & 1.334 \\
& $\mathrm{C}_{\mathrm{R}} /\left(10^{-3} \mathrm{~mm} \cdot \mathrm{a}^{-1}\right)$ & 0.081 & 0.109 & 0.771 & 8.422 & 12.5 \\
\hline
\end{tabular}

\subsection{Macroscopic Morphology of Concrete}

As illustrated in Figure $5 \mathrm{a}-\mathrm{d}$, the crack width of the reinforced concrete with copper tailing powder increased with the increase in the constant-current accelerated corrosion time. When the corrosion time was $412 \mathrm{~h}$, the reinforced concrete with copper tailing powder reached the failure limit and the crack width first decreased and then increased with the increase in the copper tailing powder content. The crack width was the smallest when the copper tailing content was $20 \%$.

Figure 6a depicts that the maximum crack widths of the specimens in Group P are 0.15 and $0.44 \mathrm{~mm}$, respectively, at 309 and $412 \mathrm{~h}$ of constant-current accelerated corrosion. According to the provisions in code for the design of concrete structures, which state that the maximum crack width of reinforced concrete members in the second and third class environments is $0.20 \mathrm{~mm}$, it is considered that this group of specimens reaches the failure limit when accelerating for $412 \mathrm{~h}$.

Figure $6 \mathrm{~b}$ depicts that the maximum crack widths of specimens in Group P10 are 0.15 and $0.22 \mathrm{~mm}$, respectively, at 309 and $412 \mathrm{~h}$ of constant-current accelerated corrosion.

Figure $6 c$ depicts that the maximum crack width of specimens in Group P20 are 0.07 and $0.20 \mathrm{~mm}$, respectively, at 309 and $412 \mathrm{~h}$ of constant-current accelerated corrosion.

Figure $6 \mathrm{~d}$ depicts that the maximum crack width of specimens in Group P30 is 0.14 and $0.26 \mathrm{~mm}$, respectively, at 309 and $412 \mathrm{~h}$ of constant-current accelerated corrosion.

The above results indicate that the specimens in all the groups reach the failure limit at $412 \mathrm{~h}$ of accelerated corrosion. In comparison with the specimens in Group P, the cracks in Groups P10, P20, and P30 were narrower, which implies that the incorporation of copper powder reduced the occurrence and development of cracks. The maximum crack widths corresponding to the specimens in Groups $\mathrm{P}$, P10, P20, and P30 at $412 \mathrm{~h}$ of constant-current accelerated corrosion were P (0.44 mm), P30 (0.26 mm), P20 $(0.22 \mathrm{~mm})$, and P10 $(0.20 \mathrm{~mm})$, from the largest to the smallest, which were consistent with the results of the electrochemical polarization curve test and analysis. 

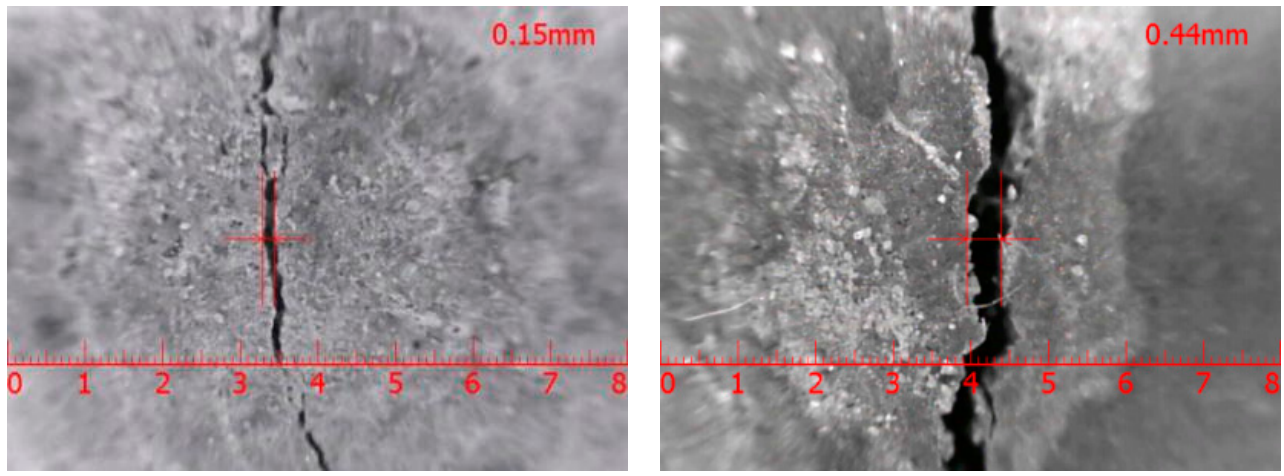

(a) Group P specimen
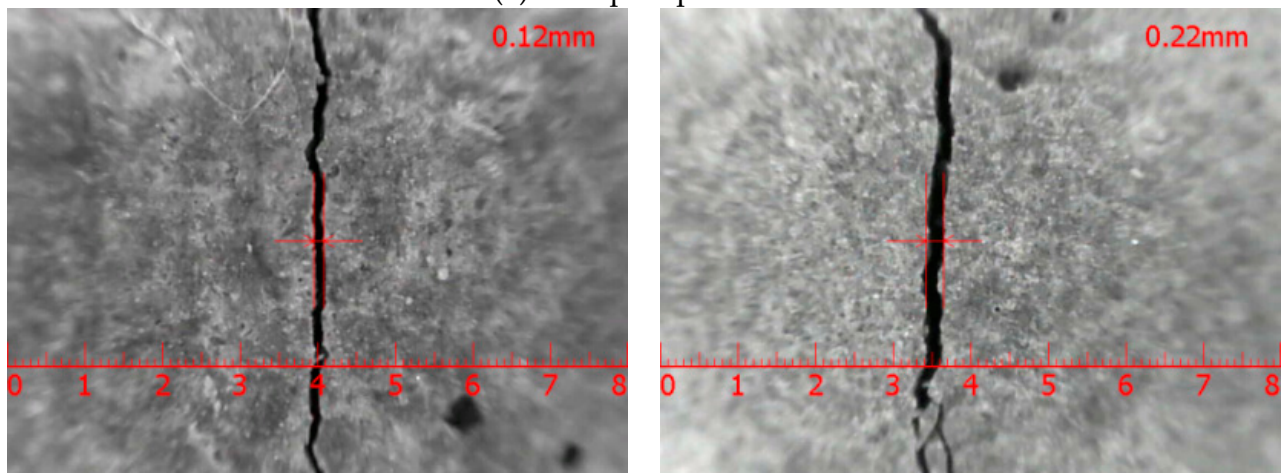

(b)Group P10 specimen
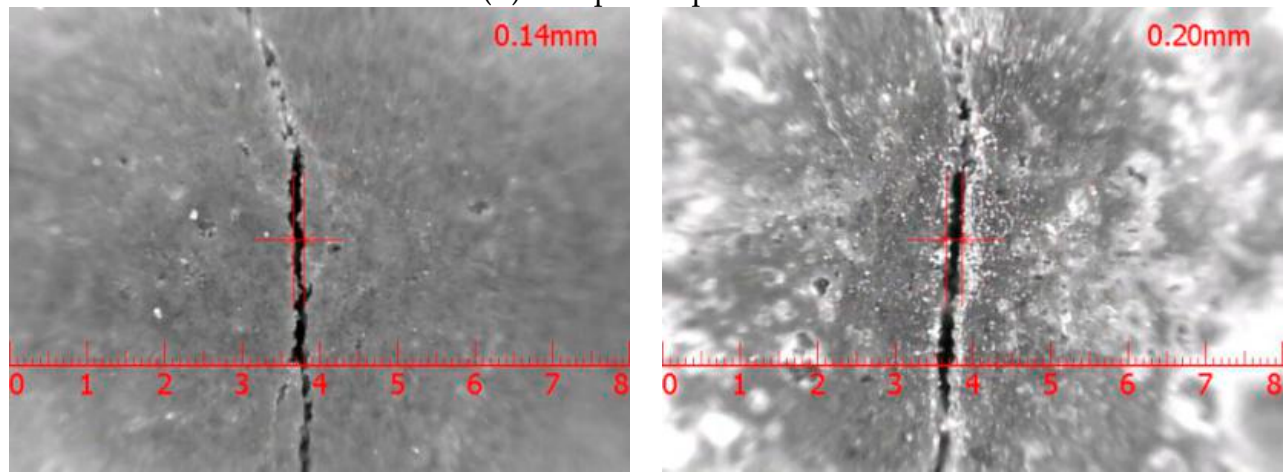

(c) Group P20 specimen
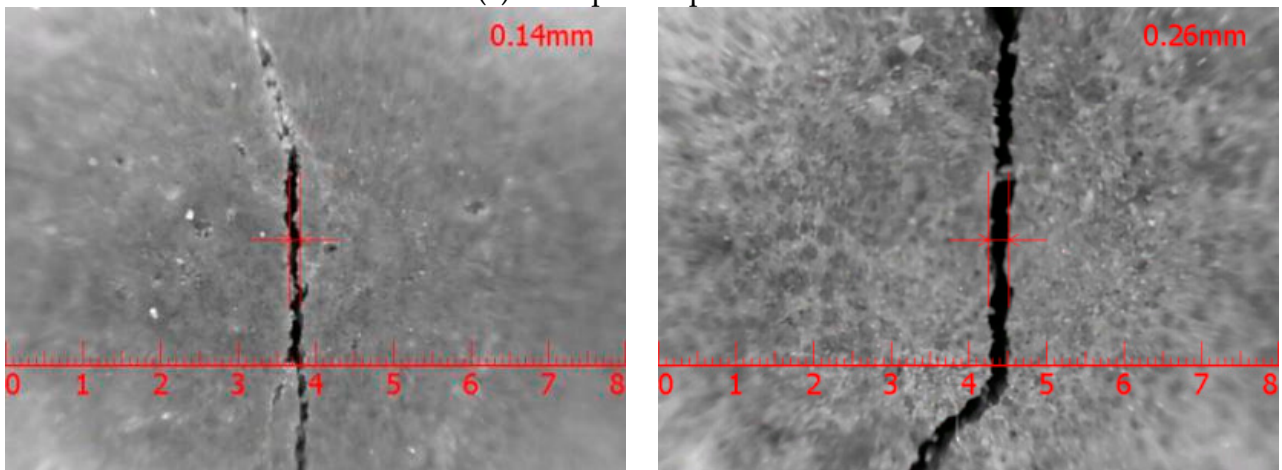

(d)Group P30 specimen

Figure 6. Effect of copper tailing powder content on crack width of concrete. (a) Constant-current acceleration test piece of Group P specimen; (b) constant-current acceleration test piece of Group P10 specimen; (c) constant-current acceleration test piece of Group P20 specimen; (d) constant-current acceleration test piece of Group P30 specimen. 


\subsection{Reinforcement Micro-Structure}

To further study the morphology of the corroded steel bars in copper tailing reinforced concrete, EDS (energy-dispersive X-ray spectroscopy) equipped with the FEG-450 thermal field emission scanning electron microscope was used to conduct the linear scanning analysis of the corroded steel bars in Groups P, P10, P20, and P30. The results are illustrated in Figures 7-10.

As can be seen from Figure 7a, at a depth of $0-90 \mu \mathrm{m}$, the concentration of $\mathrm{O}(2 \#)$ was high and fluctuated unsteadily and the concentration of $\mathrm{Fe}(1 \#)$ was also high, indicating severe corrosion of the reinforcement. Corresponding to the lighter rectangular area in Figure $6 \mathrm{~b}$, the corrosion of the reinforcement surface was severe. At a depth of about $90-160 \mu \mathrm{m}$, the concentration of O decreased, indicating a reduction in oxidation, corresponding to the darker region in Figure $7 \mathrm{~b}$, indicating that this part of the steel was not sufficiently corroded. At a depth of about 160-220 $\mu \mathrm{m}$, the concentration of $\mathrm{O}$ was close to that at the depth of $90-160 \mu \mathrm{m}$, which implies that the degree of corrosion of the steel reinforcement is close to that at the depth of $90-160 \mu \mathrm{m}$. Below a depth of $220 \mu \mathrm{m}$, the concentration of O decreased again and did not increase again, indicating that the corrosion depth of the corroded steel bar in the Group P specimen was $220 \mu \mathrm{m}$ and the corrosion was particularly severe.

As can be seen from Figure 8a, the high concentrations of $\mathrm{O}(2 \#)$ and $\mathrm{Fe}(1 \#)$ in the depth range of 0-60 $\mu \mathrm{m}$ indicates severe corrosion of the reinforcement surface, corresponding to the darker region in Figure $7 \mathrm{~b}$. At a depth of 60-180 $\mu \mathrm{m}$, the concentration of O decreased, indicating the reduction of oxidation, corresponding to the darker region in Figure $8 \mathbf{b}$, indicating that this part of the reinforcement was not fully corroded. Below a depth of $180 \mu \mathrm{m}$, the concentration of $\mathrm{O}$ decreased again and did not increase again, indicating that the corrosion depth of the corroded steel bar in the Group P10 specimen was $180 \mu \mathrm{m}$ and the corrosion was severe.

As can be seen from Figure 9a, the concentration of Fe (1\#) increased and the concentration of $\mathrm{O}(2 \#)$ began to appear at the depth of $60 \mu \mathrm{m}$ after the reinforcement in the accelerated specimen. The main corrosion products were $\mathrm{Fe}(\mathrm{OH})_{3}, \mathrm{FeOOH}$, and $\mathrm{Fe}_{2} \mathrm{O}_{3}$. At a depth of about $120 \mu \mathrm{m}$, the $\mathrm{Fe}$ and $\mathrm{O}$ concentrations were reduced, indicating insufficient oxidation, corresponding to the darker region in Figure 9b, indicating that this part of the reinforcement was not sufficiently corroded. At a depth of about $160 \mu \mathrm{m}$, the concentration of $\mathrm{O}$ decreased and did not increase, indicating that the steel bars at a depth of $160 \mu \mathrm{m}$ and above were uncorroded. This corresponds to the color boundary in Figure $9 \mathrm{~b}$ (i.e., the boundary between the corroded and uncorroded steel bars). From the comprehensive analysis of Figure 8a,b, the corrosion depth of the corroded steel bar in Group P20 was $160 \mu \mathrm{m}$ and the corrosion was relatively serious.

As can be seen from Figure 10a, the high concentrations of $\mathrm{O}(2 \#)$ and $\mathrm{Fe}(1 \#)$ at depths ranging from 30 to $190 \mu \mathrm{m}$ indicate severe corrosion of the reinforcement. Corresponding to the darker regions in Figure 10b, the corrosion of the reinforcement surface was severe. Below the depth of $190 \mathrm{~m}$, the concentration of $\mathrm{O}$ again decreased and did not increase again, indicating that the corrosion depth of the corroded steel bar in Group P30 was $190 \mu \mathrm{m}$ and the corrosion was serious.

To sum up, the reinforcement corrosion depths corresponding to the specimens in Groups P, P10, $\mathrm{P} 20$, and P30 at $412 \mathrm{~h}$ of constant-current accelerated corrosion, from largest to smallest, were $\mathrm{P}(220 \mu \mathrm{m})$, P30 $(190 \mu \mathrm{m}), \mathrm{P} 10(180 \mu \mathrm{m})$, and P20 $(160 \mu \mathrm{m})$. When the corrosion time was $412 \mathrm{~h}$, the reinforcement corrosion depth first decreased and then increased with the increase in the copper tailing powder content. The reinforcement corrosion depth was the least when the copper tailing content was $20 \%$. 


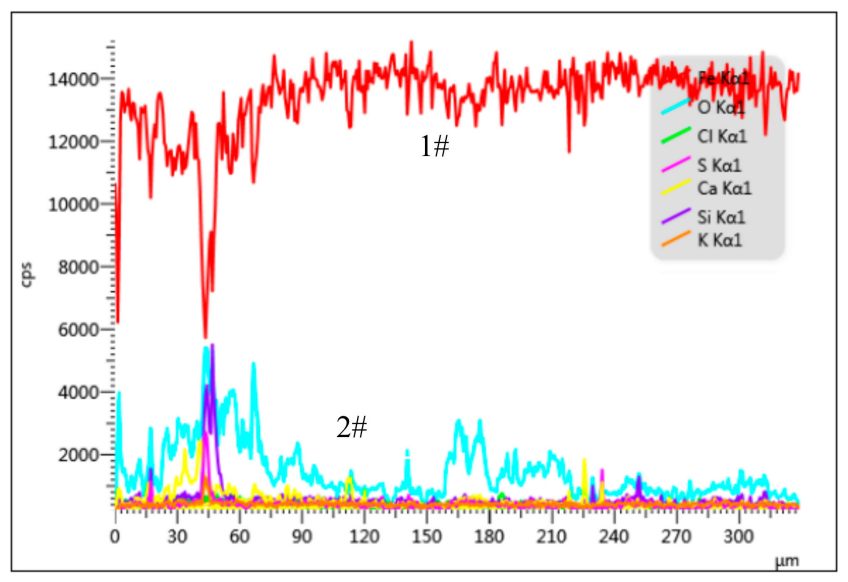

(a)

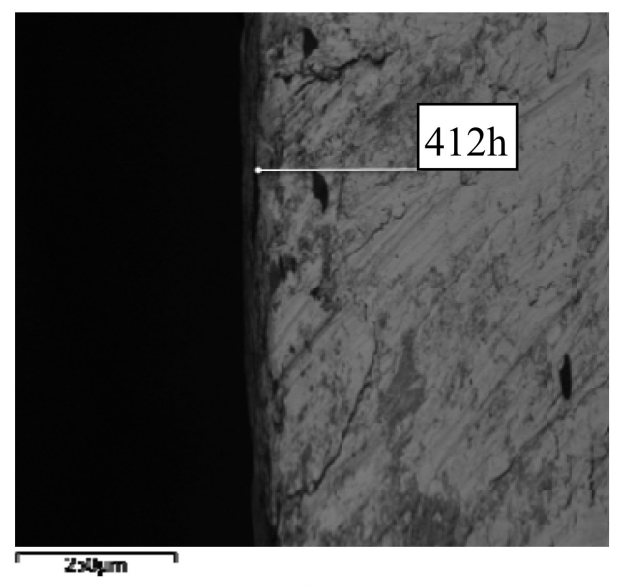

(b)

Figure 7. Group P line scan results. (a) The structure of steel corrosion products; (b) Micro-structure of corroded steel bars.

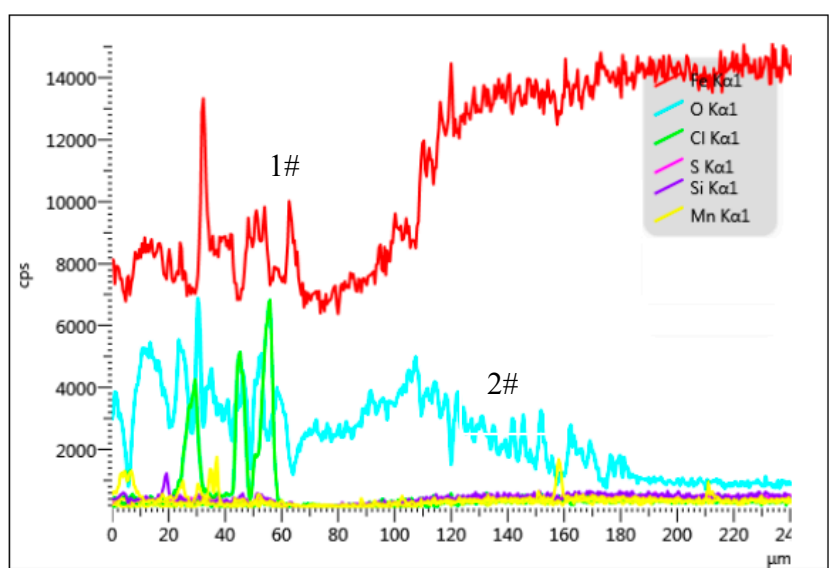

(a)

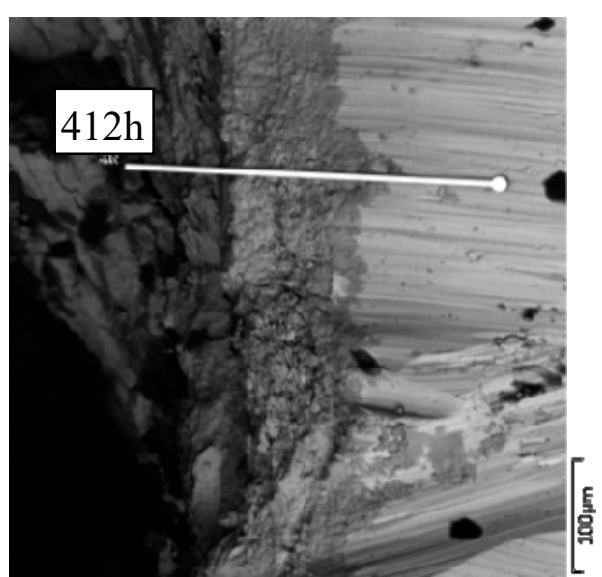

(b)

Figure 8. Group P10 line scan results. (a) The structure of steel corrosion products; (b) Micro-structure of corroded steel bars.

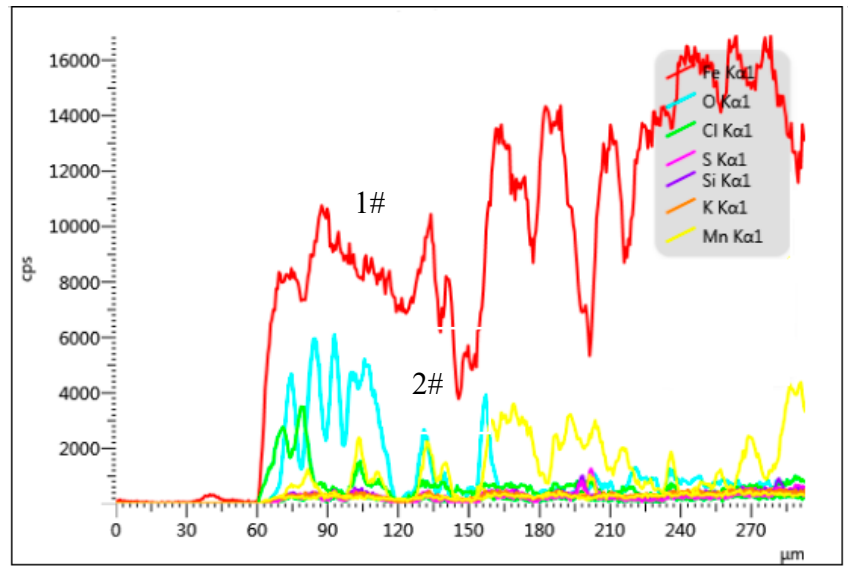

(a)

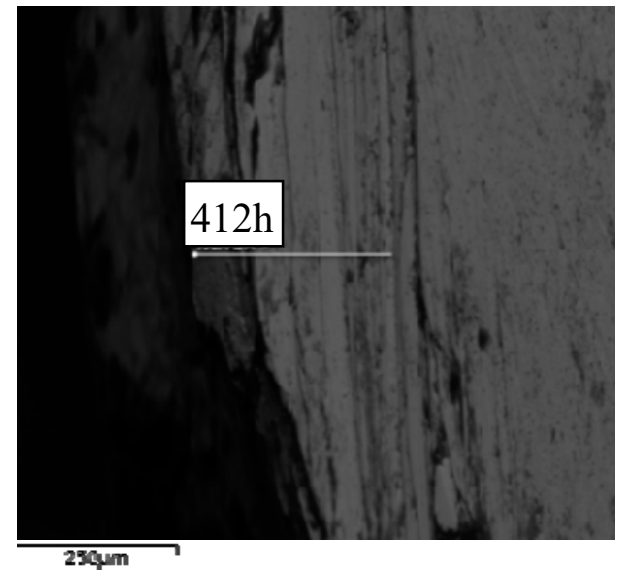

(b)

Figure 9. Group P20 line scan results. (a) The structure of steel corrosion products; (b) Micro-structure of corroded steel bars. 


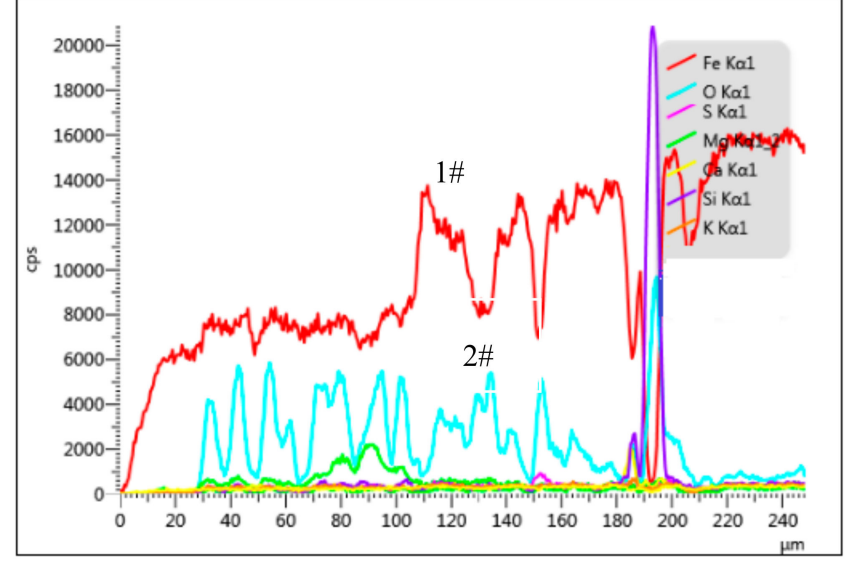

(a)

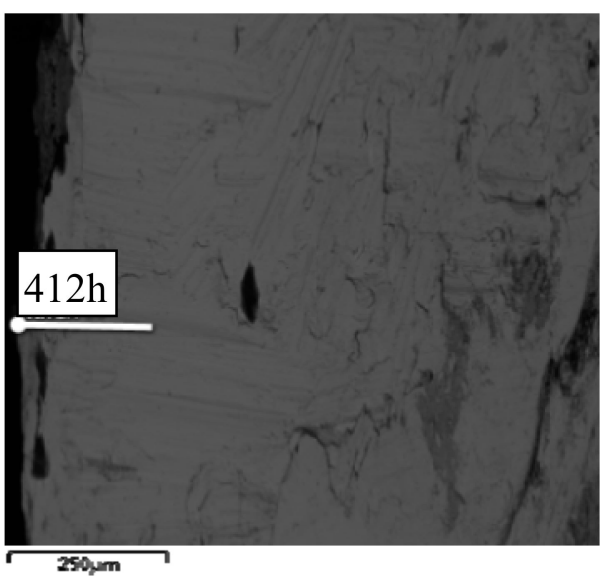

(b)

Figure 10. Group P30 line scan results. (a) The structure of steel corrosion products; (b) Micro-structure of corroded steel bars.

\section{Conclusions}

By conducting the constant-current accelerated corrosion test of reinforced concrete with different copper tailing in the brine environment of the Qinghai province, the corrosion rate, crack width, and corrosion potential of the steel reinforcement with copper tailings were studied, and the following conclusions were obtained:

1. The corrosion potential exhibited a negative trend with the extension of the accelerated constant-current corrosion, and the polarization curve passivation area gradually narrowed. At the same corrosion time, the corrosion potential decreases first and then increases with the increase in the copper tailings powder content. When the content of copper tailing powder is less than $20 \%$ of the total cement mass, the inhibition effect on the steel corrosion is better.

2. The crack width of the reinforced concrete with copper tailing powder increased with the increase in the constant-current accelerated corrosion time. The reinforced concrete with copper tailing powder reached the failure limit, and the crack width first decreased and then increased with the increase in the copper tailing powder content. When the copper tailing content is less than $30 \%$, the crack width was the smallest with $20 \%$ copper tailing content of cement quality.

3. The corrosion current density and corrosion degree of the reinforced concrete specimens with copper tailing powder increase with the increase in electrification time. After $412 \mathrm{~h}$ of constant-current accelerated corrosion, the degree of corrosion of the steel reinforcement in the specimens first decrease then increase with the increase of copper tailing powder content. The degree of corrosion of the steel reinforcement was the lowest when the copper tailing content was $20 \%$.

4. In the reinforced concrete structure of the Qinghai Salt Lake environment, the recommended content of copper tailings is $20 \%$.

Author Contributions: Conceptualization, methodology, software, data curation, writing-original draft preparation, L.Z.; funding acquisition, project administration, writing-review and editing, investigation, resources, H.Q.; validation, visualization, formal analysis, supervision, J.L.

Funding: This work was partially funded by the Science and Technology Project of the Jiangxi education department, grant number GJJ180930, and the National Key Research and Development Plan "Solid Waste Resources" Key Projects, grant number 2018YFC1903402.

Acknowledgments: The author would like to thank Sifeng Liu and Hongfa Yu for the valuable discussions on the experimental results. Electrochemical workstation: Experiments were done using facilities of the shared access center "composition of compounds" (Institute of Electron Microscopy Center, School of Materials Science and Engineering, Tsinghua University, Beijing, China).

Conflicts of Interest: The authors declare no conflicts of interest. 


\section{References}

1. Cheng, W.M.; Nie, W.; Zhou, G.; Zuo, Q.M. Study of dust suppression by atomized water from high pressure sprays in mines. J. Chin. Univ. Min. Technol. 2011, 40, 185-189.

2. Yu, L.H.; Jia, W.L.; Xue, Y.Z. Survey and analysis of the Cooper tailing resources in China. Metal Mine 2009, 39, 179-181. (In Chinese)

3. Li, H.G. Study on the influence of rain fall factors on tailings dam break and its safety warning technology. Ph.D. Thesis, University of Science \& Technology Beijing, Beijing, China, April 2017. (In Chinese).

4. Zheng, J.; Zhu, Y.; Zhao, Z. Utilization of limestone powder and water-reducing admixture in cemented paste backfill of coarse copper mine tailings. Constr. Build. Mater. 2016, 124, 31-36. [CrossRef]

5. Rahul, S.; Rizwan, A.K. Durability assessment of self compacting concrete incorporating copper slag as fine aggregates. Constr. Build. Mater. 2017, 155, 617-629.

6. Mavroulidou, M. Mechanical properties and durability of concrete with water cooled copper slag aggregate. Waste Biomass Valori. 2017, 8, 1841-1854. [CrossRef]

7. Kundu, S.; Aggarwal, A.; Mazumdar, S. Stabilization characteristics of copper mine tailings through its utilization as a partial substitute for cement in concrete: Preliminary investigations. Environ. Earth. Sci. 2016, 75, 226-235. [CrossRef]

8. Onuaguluchi, O.; Eren, Ö. Strength and durability properties of mortars containing copper tailings as a cement replacement material. Eur. J. Environ. Civil. Eng. 2013, 17, 19-31. [CrossRef]

9. Mirhosseini, S.R.; Fadaee, M.; Tabatabaei, R.; Fadaee, M.J. Mechanical properties of concrete with Sarcheshmeh mineral complex copper slag as a part of cementitious materials. Constr. Build. Mater. 2017, 134, 44-49. [CrossRef]

10. Onuaguluchi, O.; Eren, O. Copper tailings as a potential additive in concrete: Consistency, strength and toxic metal immobilization properties. Indian J. Eng. Mater. Sci. 2012, 19, 79-86.

11. Fang, Y.H.; Gu, Y.M.; Kang, Q.B.; Wen, Q.; Dai, P. Utilization of copper tailing for autoclaved sand-lime brick. Constr. Build. Mater. 2011, 25,867-872. [CrossRef]

12. Ahmari, S.; Zhang, L.Y. Production of eco-friendly bricks from copper mine tailings through geopolymerization. Constr. Build. Mater. 2012, 29, 323-331. [CrossRef]

13. Ahmari, S.; Parameswaran, K.; Zhang, L.Y. Alkali activation of copper mine tailings and low-calcium flash-furnace copper smelter slag. J. Mater. Civ. Eng. 2014, 27, 1-11. [CrossRef]

14. Zhang, L.M.; Yu, H.F.; He, Z.M. Chloride ion diffusivity of salt lake concrete. J. Cent. South Univ. (Sci. Technol.) 2011, 42, 1752-1755. (In Chinese)

15. Zhang, L.M.; Yu, H.F. Influence of dry-wet cycles on chloride diffusion coefficient. J. Hunan Univ. (Nat. Sci. Ed.) 2014, 41, 25-30. (In Chinese)

16. Yu, H.F.; Sun, W.; Wang, J.C.; Yan, L.H.; Qu, W.; Wei, Z.Y. Circumstance of salt lakes and the durability of concrete or reinforced concrete. Ind. Constr. 2003, 33, 1-4. (In Chinese)

17. Zhang, L.M.; Yu, H.F. Application of the grey system theory to predict the chloride ion capacity of concrete subjected to salt lake environment. In Proceedings of the 7th Grey Systems and Intelligent Services (GSIS), Stockholm, Sweden, 8-11 August 2017; pp. 219-223.

18. Liu, L.X. Brief introduction on the study of erosion and prevention of concrete in salt lake and saline soil area of chaerhan, chaidamu. J. Build. Mater. 2001, 4, 395-400.

19. Zheng, Y.L.; Zheng, J.Q.; Zhang, M. Experimental Study on Effect of Concrete Carbonization Degrees on Chloride Diffusion Coefficient. J. Tongji Univ. (Nat. Sci.) 2010, 38, 412-416.

20. Panda, B.; Unluer, C.; Tan, M.J. Extrusion and rheology characterization of geopolymer nanocomposites used in 3D printing. Compos. Part B Eng. 2019, 176, 1072-1090. [CrossRef]

21. Panda, B.; Tan, M.J. Rheological behavior of high volume fly ash mixtures containing micro silica for digital construction application. Mater. Lett. 2019, 237, 348-351. [CrossRef]

22. Onuaguluchi, O.; Eren, Ö. Reusing copper tailings in concrete: Corrosion performance and socioeconomic implications for the Lefke-Xeros area of Cyprus. J. Clean. Prod. 2016, 112, 420-429. [CrossRef]

23. Thomas, B.S.; Damare, A.; Gupta, R.C. Strength and durability characteristics of copper tailing concrete. Constr. Build. Mater. 2013, 48, 894-900. [CrossRef]

24. Wu, F.; Gong, J.H.; Zhang, Z. Calculation of steel corrosion rate based on corrosive crack of beams. J. Build. Struct. 2013, 34, 144-150. 
25. Abosrra, L.; Ashour, A.F.; Youseffi, M. Corrosion of steel reinforcement in concrete of di-fferent compressive strengths. Constr. Build. Mater. 2011, 25, 3915-3925. [CrossRef]

26. Ma, Y.; Che, Y.; Gong, J.X. Behavior of corrosion damaged circular reinforced concrete columns under cyclic loading. Constr. Build. Mater. 2012, 29, 548-556. [CrossRef]

27. Syed Ayub, A. A prediction model for the residual flexural strength of corroded reinforced concrete beams. Master's Thesis, King Fahd University of Petroleum and Minerals, Dhahran, Saudi Arabia, January 2005.

28. Katzer, J. Median diameter as a grading characteristic for fine aggregate cement composite designing. Constr. Build. Mater. 2012, 35, 884-887. [CrossRef]

29. Li, H.; Xu, D.L.; Feng, S.H.; Shang, B.M. Micro-structure and performance of fly ash micro-beads in cementitious material system. Constr. Build. Mater. 2014, 52, 422-427. [CrossRef]

30. Duan, P.; Shui, Z.H.; Chen, W.; Shen, C.H. Effects of metakaolin, silica fume and slag on pore structure, interfacial transition zone and compressive strength of concrete. Constr. Build. Mater. 2013, 44, 1-6. [CrossRef]

31. Zhang, Z.Q.; Zhang, B.; Yan, P.Y. Comparative study of effect of raw and densified silica fume in the paste, mortar and concrete. Constr. Build. Mater. 2016, 105, 82-93. [CrossRef]

32. Han, F.H.; Wang, Q.; Feng, J.J. The differences among the roles of ground fly ash in the paste, mortar and concrete. Constr. Build. Mater. 2015, 93, 172-179.

33. Stefanonia, M.; Angsta, U.; Elsener, B. Corrosion rate of carbon steel in carbonated concrete-A critical review. Cement Concrete Res. 2018, 103, 35-48. [CrossRef]

34. Qiao, H.X.; Li, J.C.; Wen, S.Y.; Wang, P.H.; Guo, X.K. Experimental study on anticorrosion of coated reinforcement in magnesium oxychloride concrete. J. Funct. Mater. 2018, 49, 12137-12143. (In Chinese)

35. Chen, T.; Tan, T.; Huang, W.L.; Yi, B.; Yuan, X.J.; Zhang, J.X. Polarization curve is used to measure corrosion rate and parameter optimization of galvanized parts of electric power equipment. Corros. Prot. 2014, 35, 120-123. (In Chinese)

36. Sun, W.; Zhang, Y.S.; Liu, S.F.; Zhang, Y.M. The influence of mineral admixtures on resistance to corrosion of steel bars in green high-performance concrete. Cement Concrete Res. 2004, 34, 1781-1785. [CrossRef]

37. Shi, J.J.; Sun, W. Effect of Mineral Admixtures and Steel Surface Conditions on Steel Corrosion in Mortar. J. Chin. Ceram. Soc. 2011, 39, 54-62. (In Chinese) 